Ю. О. Абрамов, д.т.н., професор, головн. н.с. (ORCID 0000-0001-7901-3768)

О. С. Басманов, д.т.н., професор, головн. н.с. (ORCID 0000-0002-6434-6575)

В. В. Олійник, к.т.н., доиент, заст. нач. каф. (ORCID 0000-0002-5193-1775)

Національний університет иивільного захисту Украӥни, Харків, Украӥна

\title{
МОДЕЛЮВАННЯ РОЗТІКАННЯ ГОРЮЧОЇ РІДИНИ ВНАСЛІДОК АВАРІЇ НА ЗАЛІЗНИЧНОМУ ТРАНСПОРТІ
}

Розглянуто прогнозування наслідків надзвичайних ситуацій, обумовлених розливом горючих рідин на залізничному транспорті шляхом побудови математичних моделей динаміки розтікання горючої рідини та ії просочення вглибину грунту. Побудовано математичну модель, що складається із системи двох диференціальних рівнянь, перше з яких є рівнянням параболічного типу і описує динаміку зміни висоти шару рідини з часом. Друге описує глибину просочення рідини в грунт. Показано, що просочення рідини вглиб підстилаючої поверхні істотно впливає на динаміку іiі розтікання і має бути враховано для правильної оцінки наслідків надзвичайної ситуації, викликаної пошкодженням цистерни з горючої рідиною. Для випадку миттєвого руйнування ємності з рідиною система рівнянь доповнюється початковими умовами, що містять особливість у вигляді $\delta$-функції у точці розливу. Показано, що математична модель поступового витікання рідини із пошкодженої ємності може бути отримана шляхом введення в диференціальне рівняння доданку, що описує джерело витікання рідини. Запропоновано метод оцінки параметрів моделі просочення рідини вглиб грунту, який базується на вимірюванні глибини просочення в певні моменти часу і пошуку таких значень показника капілярності, гідравлічної провідності і пористості грунту, які забезпечують мінімальне відхилення розрахованої глибини просочення від експериментально визначеної. При цьому для визначення розрахункової глибини використовується аналітичний розв'язок рівняння просочення рідини, а в якості критерію - мінімум суми квадратів відхилень. Побудовані моделі можуть бути використані при прогнозуванні наслідків теплового впливу пожежі розливу горючої рідини на рухомий склад та технологічні споруди залізниці.

Ключові слова: надзвичайна ситуація, розлив горючої рідини, прогнозування, розтікання i просочення

\section{1. Вступ}

Значна кількість надзвичайних ситуацій, що виникають в хімічній, переробній промисловості і на транспорті, починаються 3 аварійного розливу горючих рідин [1]. На залізничний транспорт припадає близько половини всіх вантажних перевезень в Україні. Основними причинами аварій та катастроф на залізничному транспорті $\epsilon$ несправності колій рухомого складу, засобів сигналізації, централізації та блокування, помилки диспетчерів, неуважність та халатність машиністів [2]. Найчастіше виникають надзвичайні ситуації при сході рухомого складу з колій, зіткненнях, наїздах на перепони на переїздах, при пожежах та вибухах безпосередньо у вагонах. Не виключаються розмиви залізничних колій, обвали, осипи, зсуви, затоплення. В роботі [3] проаналізовано ризики, що виникають при транспортуванні залізницею небезпечних вантажів. В [4] виявлено, що одна 3 найбільших небезпек сходження 3 рейок виникає при проходженні потяга через залізничну стрілку.

Не зважаючи на існуючі нормативні документи, що регламентують правила пожежної безпеки при перевезенні небезпечних вантажів, аварії з їх участю все одно трапляються. Це підтверджується надзвичайними ситуаціями, пов’язаними 3 розливом або горінням горючих рідин, які виникали на залізничному транспорті в Україні і світі в останні роки. 
2021 (США, Техас) - 3 рейок зійшов потяг 3 нафтопродуктами і зіткнувся 3 вантажівкою. Загорілося 3 цистерни, висота полум'я від пожежі становила кілька десятків метрів. Були евакуйовані мешканці найближчих будинків.

2021 (Росія, Саратов) - на естакаді під час вантажних робіт відбулося загорання нафтопродуктів в цистерні.

2020 (США, Аризона) - зійшли 3 рейок i спалахнули цистерни 3 легкозаймистими рідинами.

2020 (Казахстан, Жамбильська обл.) - зійшла з рейок цистерна з бензином, внаслідок чого відбувся розлив і загорання. Площа пожежі склала близько $600 \mathrm{~m}^{2}$.

2019 (Канада, Манітоба) - з рейок зійшов потяг 337 цистернами 3 нафтою, що призвело до їі часткового розливу.

2015 (Харківська обл., Шебелинка) - загорілася цистерна у складі потягу 3 40 цистерн з легкозаймистою рідиною.

2014 (Черкаська обл., Городище) - зійшов 3 рейок вантажний потяг 3 нафтопродуктами. Сталося загорання однієї цистерни, згодом вогонь охопив 11 цистерн і перекинувся на сусідню господарську будівлю.

Надзвичайні ситуації на залізничному транспорті, що супроводжуються розливом та горінням горючих і легкозаймистих рідин, є одними 3 найбільш небезпечних. Основну складність при їх ліквідації являє загроза поширення пожежі на технологічні споруди і рухомий склад. Тому важливим завданням $є$ оцінка граничного часу введення сил і засобів для охолодження рухомого складу або його евакуації. Тепловий потік від пожежі буде визначатися видом горючої рідини і параметрами розливу.

Таким чином, аналіз аварій на залізничному транспорті, обумовлених розливом горючої рідини і горінням, показав, що вони створюють загрозу як для життя і здоров'я людей, так і для рухомого складу і технічних споруд залізниці.

\section{2. Аналіз літературних даних та постановка проблеми}

В [5] проведено аналіз надзвичайних ситуацій, пов'язаних 3 розливом горючих рідин на залізничному транспорті. Запропоновано використовувати статистичні дані для розрахунку ймовірностей аварій і об'єму розлитої горючої рідини. Такий підхід дозволяє узагальнити наслідки аварій, але не дає можливості проаналізувати конкретну ситуацію. В [6] досліджується пожежа великої площі в залізничному тунелі. Особливістю підходу є розбиття всього простору на окремі зони і обчислення розподілу температур в них. При цьому сама площа пожежі вважається заданою апріорі.

В експериментальній роботі [7] досліджується динаміка розтікання nбутанола з одночасним розповсюдженням полум'я. Недоліком такого підходу $є$ залежність отриманих результатів від умов експерименту i неможливість їх узагальнення. В [8] досліджено розтікання і горіння горючих рідин на поверхні вогнетривкого скла. В [9] побудовано емпіричну модель розтікання бензину,ізооктану і етанолу на алюмінієвій підложці. Використання такого класу моделей на практиці ускладнено внаслідок того, що в реальних умовах поверхня не є ідеально гладкою, вона має нерівності та нахил.

Одним 3 поширених методів моделювання розтікання рідини по горизонтальній поверхні є використання принципу гравітаційного розтікання циліндричного шару рідини (рис. 1) [10]. 


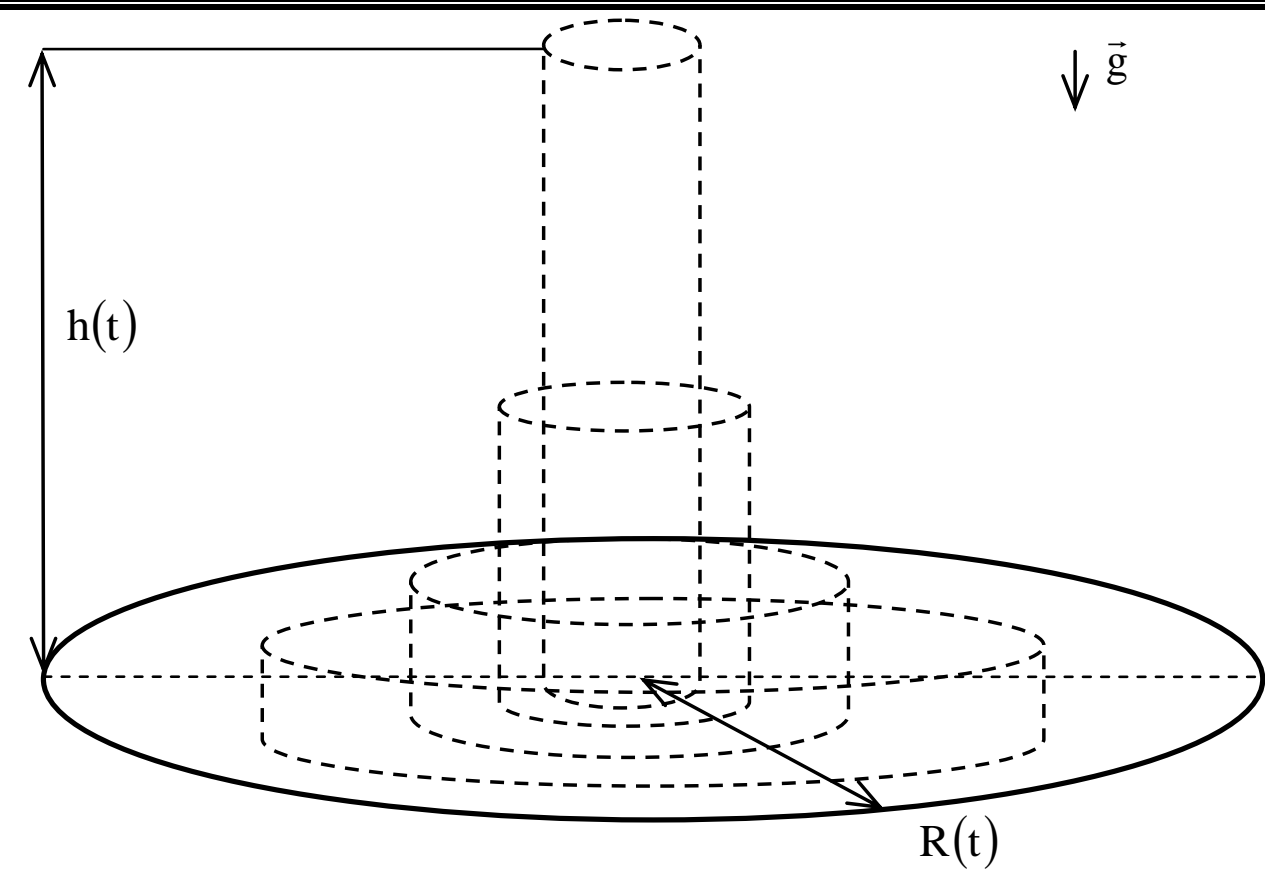

Рис. 1. Принцип розрахунку гравітаційного розтікання циліндричного шару рідини

В початковий момент часу $\mathrm{t}=0$ рідина являє собою циліндр висотою $\mathrm{h}_{0}$ и радіусом $\mathrm{R}_{0}$. Під впливом сили тяжіння рідина розтікається, зберігаючи в кожний момент часу $\mathrm{t}$ форму циліндра з радіусом $\mathrm{R}(\mathrm{t}) \geq \mathrm{R}_{0}$ и висотою $\mathrm{h}(\mathrm{t}) \leq \mathrm{h}_{0}$. Динаміка зміни радіусу розливу визначається балансом сил и описується рівнянням

$$
\begin{gathered}
\mathrm{R}^{\prime \prime}=\frac{\mathrm{gV}(\mathrm{t})}{\pi \mathrm{R}^{3}}-0,455\left(\lg \frac{2 \mathrm{R}\left|\mathrm{R}^{\prime}\right|}{\mathrm{v}}\right)^{-2,58} \frac{2\left|\mathrm{R}^{\prime}\right| \mathrm{R}^{\prime}}{\mathrm{V}(\mathrm{t})} \pi \mathrm{R}^{2}-\frac{\sqrt{2} \pi \mathrm{c}_{\mathrm{d}} \mathrm{c}_{1}^{3} \mathrm{R}^{\prime}\left|\mathrm{R}^{\prime}\right| \mathrm{R}^{2}}{\mathrm{~V}(\mathrm{t})}- \\
-\frac{2 \pi \mathrm{R} \sigma}{\rho \mathrm{V}(\mathrm{t})}
\end{gathered}
$$

де $\mathrm{R}=\mathrm{R}(\mathrm{t})$ - радіус розливу; $\mathrm{V}(\mathrm{t})$ - об'єм розлитої рідини; $\mathrm{c}_{\mathrm{d}}=0,09, \mathrm{c}_{1}=0,25$ емпіричні константи; $\sigma$ - коефіцієнт поверхневого натягу рідини; $\rho$ - щільність рідини. Розтікання закінчиться тоді, коли сила поверхневого натягу врівноважить гравітаційну силу, що змушує рідину розтікатися.

Основним недоліком моделі гравітаційного розтікання $є$ відсутність врахування просочення рідини вглибину грунту. Також ця модель не може бути застосована на похилій поверхні.

Аналізу моделей розтікання рідини на твердій поверхні присвячено роботу [11]. В ній на підставі порівняння розрахунків за моделлю [12] і експериментальних даних запропоновано модифікацію моделі. Недоліком такого підходу є те, що запропонована корекція залежить від умов, в яких були проведені експериментальні дослідження.

Аналіз моделей розтікання горючих рідин, засвідчив, що вони не враховують просочення рідини в підстилаючу поверхню. Це, в свою чергу, призводить до похибок в оцінці розмірів розливу, та динаміки його утворення. 


\section{3. Мета та завдання дослідження}

Метою роботи $є$ прогнозування наслідків надзвичайних ситуацій, обумовлених розливом горючих рідин на залізничному транспорті, шляхом побудови математичних моделей динаміки розтікання горючої рідини і iï просочення вглиб грунту.

Для досягнення поставленої мети необхідно вирішити наступні завдання:

- побудувати модель розтікання рідини з одночасним іiі просочення вглиб підстилаючої поверхні;

- розробити метод оцінки параметрів моделі просочення рідини вглиб грунту.

\section{4. Розробка моделі розтікання рідини з її одночасним просоченням}

Просочування рідини вглиб підстилаючої поверхні описується моделлю Грін-Ампт (Green-Ampt) [13], згідно 3 якою розглядається межа між вже змоченим і ще сухим грунтом (рис. 2).

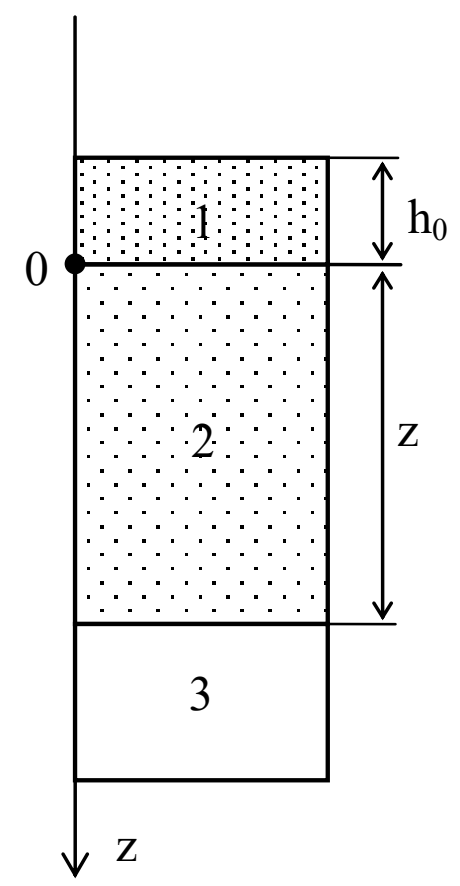

Рис. 2. Просочення рідини вглиб підстилаючої поверхні: 1 - рідина га поверхні; 2 змочений грунт; 3 - сухий грунт

Просочування рідини вглиб призводить до переміщення межи між змоченим і сухим грунтом. Швидкість просочування

$$
\mathrm{q}=\frac{\partial \mathrm{z}}{\partial \mathrm{t}}
$$

описується законом Дарсі

$$
\mathrm{q}=\mathrm{K} \frac{\partial \mathrm{H}}{\partial \mathrm{z}} \approx \mathrm{K} \frac{\Delta \mathrm{H}}{\mathrm{z}}
$$

де $\mathrm{K}$ - гідравлічна провідність змоченого грунту; $\frac{\partial \mathrm{H}}{\partial \mathrm{z}}$ - гідравлічний градієнт; 


$$
\Delta \mathrm{H}=\mathrm{h}_{0}+\mathrm{z}+\mathrm{h}_{\mathrm{f}}
$$

$\mathrm{h}_{0}$ - товщина шару рідини на поверхні; $\mathrm{z}$ - товщина змоченого шару грунту; $\mathrm{h}_{\mathrm{f}}$ - показник капілярності (suction head), що описує тиск втягування рідини вглиб грунту внаслідок капілярного ефекту. Об'єднуючи вирази (2)-(4), отримаємо рівняння просочування рідини

$$
\frac{\partial \mathrm{z}}{\partial \mathrm{t}}=\mathrm{K} \frac{\mathrm{h}_{0}+\mathrm{z}+\mathrm{h}_{\mathrm{f}}}{\mathrm{z}}
$$

Просочування рідини вглиб грунту призводить до зменшення товщини іiі шару на поверхні. Якщо $\phi-$ коефіцієнт пористості грунту, тобто об'ємна доля води, що міститься в змоченому грунті, то збільшення глибини просочення на $\Delta \mathrm{z}$ призводить до зменшення шару рідини на поверхні на $\Delta \mathrm{h}_{0}$ :

$$
\begin{aligned}
& \Delta \mathrm{h}_{0}=-\phi \Delta \mathrm{z} \\
& \frac{\partial \mathrm{h}_{0}}{\partial \mathrm{t}}=-\phi \frac{\partial \mathrm{z}}{\partial \mathrm{t}} .
\end{aligned}
$$

Таким чином, при наявності шару рідини на поверхні $\left(\mathrm{h}_{0}>0\right)$ динаміка просочування описується системою рівнянь (5)-(6). А після того, як рідини на поверхні не залишиться $\left(\mathrm{h}_{0}=0\right)$, одним рівнянням

$$
\frac{\partial \mathrm{z}}{\partial \mathrm{t}}=\mathrm{K} \frac{\mathrm{z}+\mathrm{h}_{\mathrm{f}}}{\mathrm{z}}
$$

Гідравлічна провідність змоченого грунту К описується залежністю

$$
\mathrm{K}=\frac{\mathrm{k} \rho \mathrm{g}}{\mu}
$$

$\mu$ - динамічна в'язкість рідини (Па·с); $\mathrm{k}$ - проникність підстилаючої поверхні $\left(\mathrm{M}^{2}\right)$. Враховуючи залежність

$$
v=\frac{\mu}{\rho}
$$

де $v$ - кінематична в'язкість $\left(\mathrm{M}^{2} / \mathrm{c}\right)$, вираз (8) може бути записаний у вигляді

$$
\mathrm{K}=\frac{\mathrm{kg}}{\mathrm{v}}
$$

Розтікання рідини на горизонтальній поверхні описується диференціальним рівнянням параболічного типу 340 ю. О. Абрамов, О. Є. Басманов, в. В. олійник 


$$
\frac{\partial \mathrm{h}}{\partial \mathrm{t}}=\mathrm{R}\left[\frac{\partial}{\partial \mathrm{x}}\left[\mathrm{h}^{3}\left(\frac{\partial \mathrm{h}}{\partial \mathrm{x}}\right)\right]+\frac{\partial}{\partial \mathrm{y}}\left[\mathrm{h}^{3}\left(\frac{\partial \mathrm{h}}{\partial \mathrm{y}}\right)\right]-\gamma \frac{\partial}{\partial \mathrm{x}} \mathrm{h}^{3}\right]
$$

де $\mathrm{R}$ - ефективний коефіцієнт дифузії:

$$
\mathrm{R}=\frac{\rho g}{3 \mu} \cos \theta=\frac{\mathrm{g}}{3 v} \cos \theta
$$

$\gamma=\operatorname{tg} \theta ; \theta-$ кут нахилу поверхні; $\mathrm{h}(\mathrm{x}, \mathrm{y})$ - висота рідини у точці $(\mathrm{x}, \mathrm{y})$, обчислена вздовж нормалі до поверхні. При цьому розташування системи координат обрано таким чином, щоб напрямок нахилу поверхні співпадав 3 віссю ОХ.

При побудові моделі розтікання рідини, яка враховує їі просочення вглиб підстилаючої поверхні, будемо виходити із припущення, що просочення рідини відбувається лише в вертикальному напрямку. Тому, введемо в рівняння (11) доданок, що буде відповідати просоченню в грунт

$$
\frac{\partial \mathrm{h}}{\partial \mathrm{t}}=\mathrm{R}\left[\frac{\partial}{\partial \mathrm{x}}\left[\mathrm{h}^{3}\left(\frac{\partial \mathrm{h}}{\partial \mathrm{x}}\right)\right]+\frac{\partial}{\partial \mathrm{y}}\left[\mathrm{h}^{3}\left(\frac{\partial \mathrm{h}}{\partial \mathrm{y}}\right)\right]-\gamma \frac{\partial}{\partial \mathrm{x}} \mathrm{h}^{3}\right]-\phi \mathrm{K} \frac{\mathrm{h}+\mathrm{z}+\mathrm{h}_{\mathrm{f}}}{\mathrm{z}}
$$

де $\mathrm{z}=\mathrm{z}(\mathrm{x}, \mathrm{y})$ - глибина просочення в точці $(\mathrm{x}, \mathrm{y})$ розливу. Рівняння (12) разом 3 рівнянням

$$
\frac{\partial \mathrm{z}}{\partial \mathrm{t}}=\mathrm{K} \frac{\mathrm{h}+\mathrm{z}+\mathrm{h}_{\mathrm{f}}}{\mathrm{z}}
$$

утворюють систему, що описує розтікання рідини з одночасним ії просоченням.

У випадку миттєвого розливу об'ємом $\mathrm{V}$, що стався в момент часу $\mathrm{t}=0 \mathrm{y}$ точці початку координат $(0,0)$, система (12)-(13) доповнюється початковою умовою

$$
\begin{gathered}
\mathrm{h}(\mathrm{x}, \mathrm{y})=\mathrm{V} \delta(\mathrm{x}) \delta(\mathrm{y}), \\
\mathrm{z}(\mathrm{x}, \mathrm{y})=0,
\end{gathered}
$$

де $\delta(\mathrm{x})$ - дельта-функція Дірака.

Для тривалого в часі витікання рідини система рівнянь розтікання i просочення набуває вигляду

$$
\begin{aligned}
\frac{\partial \mathrm{h}}{\partial \mathrm{t}}=\mathrm{R}\left[\frac{\partial}{\partial \mathrm{x}}\left[\mathrm{h}^{3}\left(\frac{\partial \mathrm{h}}{\partial \mathrm{x}}\right)\right]+\right. & \left.\frac{\partial}{\partial \mathrm{y}}\left[\mathrm{h}^{3}\left(\frac{\partial \mathrm{h}}{\partial \mathrm{y}}\right)\right]-\gamma \frac{\partial}{\partial \mathrm{x}} \mathrm{h}^{3}\right]-\phi \mathrm{K} \frac{\mathrm{h}+\mathrm{z}+\mathrm{h}_{\mathrm{f}}}{\mathrm{z}}+ \\
+\mathrm{v}(\mathrm{t}) \delta(\mathrm{x}) \delta(\mathrm{y}) ; & \frac{\partial \mathrm{z}}{\partial \mathrm{t}}=\mathrm{K} \frac{\mathrm{h}+\mathrm{z}+\mathrm{h}_{\mathrm{f}}}{\mathrm{z}},
\end{aligned}
$$


3 нульовою початковою умовою

$$
\mathrm{h}(\mathrm{x}, \mathrm{y})=0, \mathrm{z}(\mathrm{x}, \mathrm{y})=0
$$

де $\mathrm{v}(\mathrm{t})$ - об'ємна швидкість витікання рідини $\left(\mathrm{m}^{3} / \mathrm{c}\right)$.

\section{5. Оцінка параметрів моделі просочування рідини вглиб підстилаючої поверхні}

Загальний розв’язок рівняння (6) має вигляд

$$
\mathrm{h}_{0}=-\phi \mathrm{z}+\mathrm{c}_{0}
$$

де $\mathrm{c}_{0}$ - стала, що визначається із початкової умови і дорівнює початковому рівню рідини на поверхні. Підстановка співвідношення (19) в рівняння (5) дає

$$
\frac{\partial \mathrm{z}}{\partial \mathrm{t}}=\mathrm{K} \frac{\mathrm{c}_{0}-\phi \mathrm{z}+\mathrm{z}+\mathrm{h}_{\mathrm{f}}}{\mathrm{z}}, \mathrm{c}_{0}-\phi \mathrm{z}>0
$$

Об’єднуючи рівняння (7) і (20), отримаємо

$$
\frac{\partial \mathrm{z}}{\partial \mathrm{t}}=\mathrm{K} \frac{\eta\left(\mathrm{c}_{0}-\phi \mathrm{z}\right)+\mathrm{z}+\mathrm{h}_{\mathrm{f}}}{\mathrm{z}},
$$

де $\eta(x)=\left\{\begin{array}{l}x, x>0 \\ 0, x \leq 0\end{array}\right.$

Таким чином, динаміка просочування рідини вглиб грунту буде описуватися нелінійним диференціальним рівнянням (21) з початковою умовою

$$
\mathrm{z}(0)=0
$$

Для аналітичного розв'язання рівняння (21) в області $\mathrm{c}_{0}-\phi \mathrm{z}>0$ введемо позначення

$$
\mathrm{A}=\mathrm{K}\left(\mathrm{c}_{0}+\mathrm{h}_{\mathrm{f}}\right), \mathrm{B}=\mathrm{K}(1-\phi)
$$

які перетворюють його на

$$
\begin{aligned}
& \frac{\mathrm{dz}}{\mathrm{dt}}=\frac{\mathrm{A}+\mathrm{Bz}}{\mathrm{z}} \\
& \frac{\mathrm{z}}{\mathrm{A}+\mathrm{Bz}} \mathrm{dz}=\mathrm{dt}
\end{aligned}
$$

Інтегруючи обидві частини рівняння, отримаємо 


$$
\frac{\mathrm{z}}{\mathrm{B}}-\frac{\mathrm{A} \ln (\mathrm{A}+\mathrm{Bz})}{\mathrm{B}^{2}}+\mathrm{D}=\mathrm{t} \text {, }
$$

де $\mathrm{D}$ - стала інтегрування, значення якої визначається початковою умовою (22). Тоді

$$
\mathrm{D}=\frac{\mathrm{A} \ln \mathrm{A}}{\mathrm{B}^{2}}
$$

Таким чином,

$$
\begin{gathered}
\frac{\mathrm{z}}{\mathrm{B}}-\frac{\mathrm{A}}{\mathrm{B}^{2}} \ln \left(1+\frac{\mathrm{B}}{\mathrm{A}} \mathrm{z}\right)=\mathrm{t} \\
\frac{\mathrm{z}}{\mathrm{K}(1-\phi)}-\frac{\mathrm{c}_{0}+\mathrm{h}_{\mathrm{f}}}{\mathrm{K}(1-\phi)^{2}} \ln \left(1+\frac{1-\phi}{\mathrm{c}_{0}+\mathrm{h}_{\mathrm{f}}} \mathrm{z}\right)=\mathrm{t}, \mathrm{c}_{0}-\phi \mathrm{z}>0 .
\end{gathered}
$$

Iз (23) випливає формула для часу повного просочення рідини в грунт $\left(\mathrm{c}_{0}-\phi \mathrm{z}=0\right)$ :

$$
\begin{gathered}
\mathrm{t}_{\mathrm{inf}}=\frac{\mathrm{c}_{0}}{\mathrm{~K}(1-\phi) \phi}-\frac{\mathrm{c}_{0}+\mathrm{h}_{\mathrm{f}}}{\mathrm{K}(1-\phi)^{2}} \ln \left(1+\frac{1-\phi}{\mathrm{c}_{0}+\mathrm{h}_{\mathrm{f}}} \frac{\mathrm{c}_{0}}{\phi}\right) \\
\mathrm{t}_{\mathrm{inf}}=\frac{\mathrm{c}_{0}}{\mathrm{~K}(1-\phi) \phi}-\frac{\mathrm{c}_{0}+\mathrm{h}_{\mathrm{f}}}{\mathrm{K}(1-\phi)^{2}} \ln \left(\frac{\mathrm{c}_{0}+\phi \mathrm{h}_{\mathrm{f}}}{\phi \mathrm{c}_{0}+\phi \mathrm{h}_{\mathrm{f}}}\right)
\end{gathered}
$$

На рис. 3 показано динаміку просочення рідини на прикладі води і сухого піску, де $\mathrm{K}=1,3 \cdot 10^{-4} \mathrm{M} / \mathrm{c}, \phi=0,43 ; \mathrm{h}_{\mathrm{f}}=0,24 \mathrm{м}$. Початкова висота шару рідини була прийнята $\mathrm{c}_{0}=1 \mathrm{~cm}$.

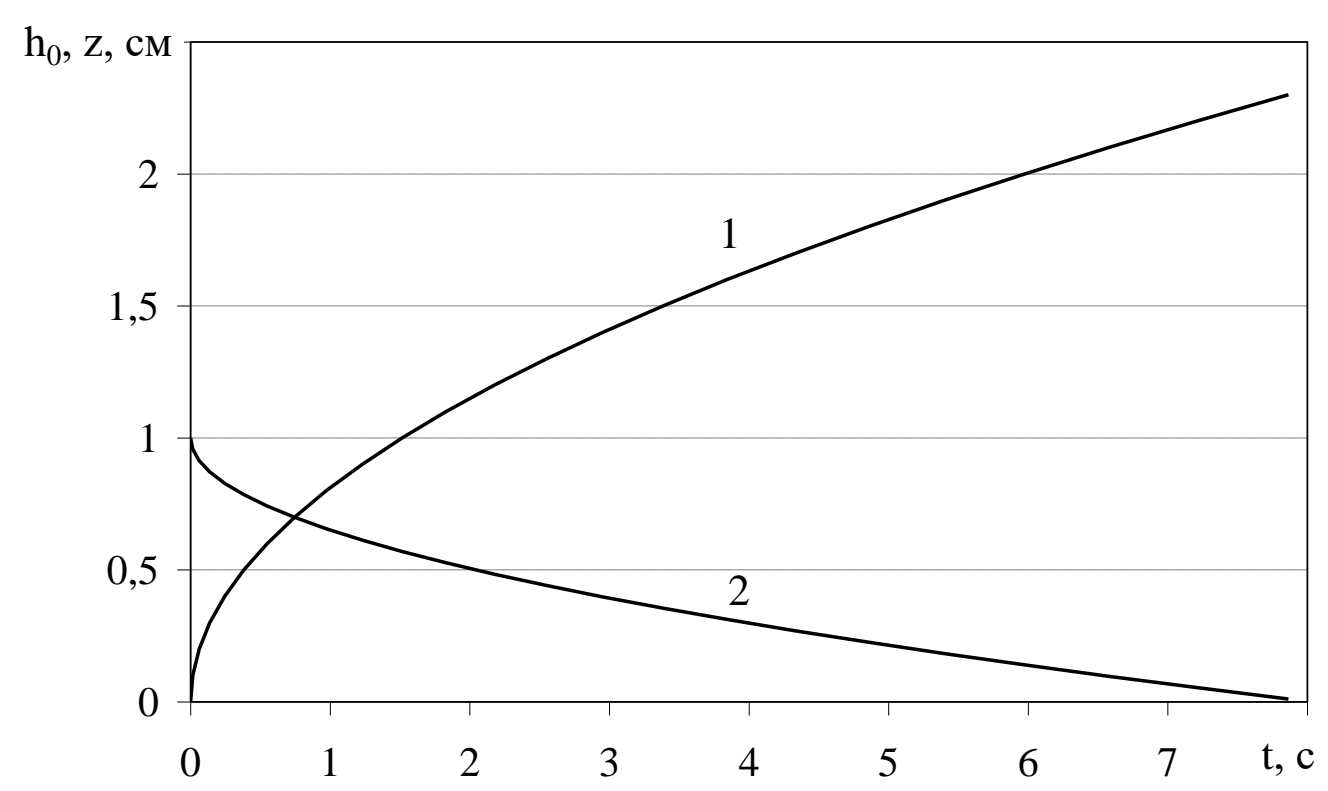

Рис. 3. Динаміка просочення рідини вглиб підстилаючої поверхні: 1 - глибина просочення; 2 - товщина шару на поверхні; 3 - сухий грунт

Civi1 Security. DOI: $10.52363 / 2524-0226-2021-33-3$ 
При цьому час повного просочення рідини складає близько 8 с.

Для практичного використання моделей (21), (23), (24) необхідно знати проникність підстилаючої поверхні $\mathrm{k}$, показник капілярності $\mathrm{h}_{\mathrm{f}} \mathrm{i}$ коефіцієнт пористості грунту $\phi$. Їх значення для деяких типів грунту і рідин наведено в [14]. В загальному випадку їх необхідно визначити експериментально. Нехай в моменти часу $\mathrm{t}_{1}, \mathrm{t}_{2} \ldots, \mathrm{t}_{\mathrm{n}}$ вимірюється глибина просочення $\mathrm{z}_{1}, \mathrm{z}_{2}, \ldots, \mathrm{z}_{\mathrm{n}}$. Запишемо функцію похибки

$$
\mathrm{L}=\sum_{\mathrm{i}=1}^{\mathrm{n}}\left(\mathrm{z}_{\mathrm{n}}-\mathrm{F}\left(\mathrm{t}_{\mathrm{n}}\right)\right)^{2}
$$

де $\mathrm{F}(\mathrm{t})$ - розв'язок алгебраїчного рівняння (23). Тоді оцінка параметрів $\mathrm{k}$, $\mathrm{h}_{\mathrm{f}}, \phi$ зводитися до розв'язання задачі мінімізації

$$
\mathrm{L}=\sum_{\mathrm{i}=1}^{\mathrm{n}}\left(\mathrm{z}_{\mathrm{n}}-\mathrm{F}\left(\mathrm{t}_{\mathrm{n}}\right)\right)^{2} \rightarrow \min _{\mathrm{k}, \mathrm{h}_{\mathrm{f}}, \phi}
$$

Значення $\mathrm{k}, \mathrm{h}_{\mathrm{f}}, \phi$, що забезпечують мінімум функції (25), i будуть оцінками відповідних параметрів.

\section{6. Обговорення результатів побудови моделі розтікання рідини на поверхні грунту}

Розтікання рідини на поверхні грунту супроводжується іiі просоченням вглибину. У зв'язку з цим, математична модель цього процесу являє собою сукупність диференціального рівняння параболічного типу, що описує розповсюдження рідини по поверхні, диференціального рівняння першого порядку, що описує просочення рідини вглиб підстилаючої поверхні, а також початкової умови, яка відповідає ситуації, що передує надзвичайній ситуації.

За характером розтікання розрізняють миттєвий розлив і такий, що триває в часі. Перший має місце при катастрофічному руйнуванні ємності із рідиною, а другий - при ушкодженні ємності, яке призводить до поступового витікання рідини 3 неї. Відзначимо, що миттєве витікання $є$ граничним випадком довготривалого витікання, якщо час витікання скорочується, прямуючи до нуля, а загальний об'єм розлитої рідини залишається сталим.

Випадок миттєвого розливу описує система рівнянь (12)-(13) 3 початковими умовами (14)-(15), що містять в собі $\delta$-функцію Дірака, яка є математичним описом факту миттєвого розливу в початковий момент часу. Для тривалого розливу мають місце нульові початкові умови (18), натомість система рівняння (16)-(17) містить функцію, що відповідає триваючому у часі джерелу витікання рідини.

Введення в систему рівнянь доданку $\gamma \frac{\partial}{\partial \mathrm{x}} \mathrm{h}^{3}$ дозволяє врахувати нахил поверхні i розглядати розтікання на похилій поверхні. Швидкість розтікання рідини визначається ії кінематичною в'язкістю: більш в'язкі рідини розтікаються повільніше. 
Для практичного використання отриманих моделей необхідно розв'язати системи рівнянь (12)-(13) і (16)-(17) із відповідними початковими умовами. Знаходження аналітичного розв'язку $є$ неможливим внаслідок нелінійності рівнянь по невідомим функціям (товщини шару рідини і глибини просочення). Отже для цього мають бути застосовані чисельні методи, зокрема, метод сіток.

Аналіз рівняння (21) показує, що інтенсивність просочення залежить від фізичних властивостей рідини і підстилаючої поверхні. Інтенсивність просочення буде тим більшою, чим меншою є кінематична в’язкість рідини. Розгляд рівняння просочення рідини окремо від iї розтікання дозволяє знайти його аналітичний розв'язок i, зокрема, визначити час повного просочення рідини вглиб підстилаючої поверхні. Цей розв'язок також може бути використаний для емпіричного визначення таких властивостей, як показник капілярності, гідравлічна провідність змоченого грунту і коефіцієнт пористості.

Запропонований метод оцінки параметрів моделі просочення рідини вглиб грунту включає вимірювання глибини просочення в певні моменти часу і пошук таких значень показника капілярності, проникності (або гідравлічної провідності) і пористості грунту, які забезпечують мінімум відхилення розрахованої глибини просочення від експериментально визначеної. Відзначимо, що показник капілярності і гідравлічна провідність є характеристиками пари «грунт - рідина». Типові значення коефіцієнта пористості лежать в діапазоні від 0,09 (асфальт) до 0,45 (пісок), гідравлічної провідності піску, глини, чорнозему $-\left(10^{-4} \div 10^{-8}\right) \mathrm{M} / \mathrm{c}$, показника капілярності - $\left(10^{-2} \div 1\right)$ м.

На прикладі води і сухого піску показано, що час повного просочення шару рідини товщиною $1 \mathrm{~cm}$ складає близько $8 \mathrm{c}$. Просочення рідини вглибину підстилаючої поверхні зменшує розміри розливу. Отже врахування цього ефекту необхідно для правильної оцінки наслідків надзвичайної ситуації, викликаної пошкодженням цистерни з горючої рідиною.

Побудована модель може бути використана при прогнозуванні наслідків теплового впливу пожежі розливу горючої рідини на рухомий склад та технологічні споруди залізниці [14].

\section{7. Висновки}

1. Побудовано математичну модель, що складається із системи двох диференційних рівнянь і описує динаміку розтікання рідини по поверхні 3 одночасним iï просоченням вглиб. Показано, що у випадку миттєвого руйнування ємності з рідиною, математична модель розтікання і просочення рідини має буди доповнена початковими умовами 3 особливістю у вигляді $\delta$-функції у точці розливу. У випадку поступового витікання рідини із ємності, викликаного іiі пошкодженням, у систему диференційних рівнянь має бути введений доданок, що відповідає об'ємній швидкості витікання рідини із ємності. На прикладі води і сухого піску показано, що час повного просочення шару рідини товщиною $1 \mathrm{~cm}$ складає близько 8 с. Таким чином, просочення рідини вглиб підстилаючої поверхні істотно впливає на динаміку іï розтікання і має бути враховано при оцінці наслідків розливу.

2. Розроблено метод оцінки параметрів моделі просочення рідини вглиб грунту, який включає вимірювання глибини просочення в певні моменти часу і пошук таких значень показника капілярності, проникності і пористості грунту, які забезпечують Civit security. DOI: $10.52363 / 2524-0226-2021-33-3$ 
мінімум відхилення розрахованої глибини просочення від експериментально визначеної. При цьому для визначення розрахункової глибини використовується аналітичний розв'язок рівняння просочення рідини, а в якості критерію - мінімум суми квадратів відхилень. Типові значення коефіцієнта пористості лежать в діапазоні від 0,09 (асфальт) до 0,45 (пісок), гідравлічної провідності піску, глини, чорнозему $(10-4 \div 10-8)$ м/с, показника капілярності - $(10-2 \div 1)$ м.

\section{Література}

1. Raja S., Tauseef S. M., Abbasi T., et al. Risk of Fuel Spills and the Transient Models of Spill Area Forecasting // Journal of Failure Analysis and Prevention. 2018. V. 18. Р. 445-455. doi: 10.1007/s11668-018-0429-1

2. Чернецький В. В., Федунків В. С., Кочкодан Т. Й. Організація управління силами та засобами оперативно-рятувальної служби цивільного захисту при ліквідації пожеж нафтопродуктів на залізничному транспорті // Проблеми цивільного захисту: управління, попередження, аварійно-рятувальні та спеціальні роботи. 2015. С. 131-137. URL: http://edu-mns.org.ua/img/news/6041/fedunkiv.doc

3. Huang W., Shuai B., Zuo B., Xu Y., Antwi E. A. systematic railway dangerous goods transportation system risk analysis approach: The 24 model // Journal of Loss Prevention in the Process Industries. 2019. V. 61. P. 94-103. doi: 10.1016/j.jlp.2019.05.021

4. Dindar S., Kaewunruen S., An. M, Osman M. H. Natural Hazard Risks on Railway Turnout Systems // Natural Hazard Risks on Railway Turnout Systems. 2016. V. 161. P. 1254-1259. doi: 10.1016/j.proeng.2016.08.561

5. Etkin D., Horn M., Wolford A. CBR-Spill RISK: Model to Calculate Crude-byRail Probabilities and Spill Volumes // International Oil Spill Conference Proceedings. 2017. P. 3189-3210. doi: 10.7901/2169-3358-2017.1.3189

6. Zhao X., Chen C., Shi C., Zhao D. An extended model for predicting the temperature distribution of large area fire ascribed to multiple fuel source in tunnel // Tunnelling and Underground Space Technology. 2019. V. 85. P. 252-258. doi: 10.1016/j.tust.2018.12.013

7. Pan Y., Li M., Luo X., Wang C., Luo Q., Li J. Analysis of heat transfer of spilling fire spread over steady flow of n-butanol fuel // International Communications in Heat and Mass Transfer. 2020. 116 (104685). doi: 10.1016/j.icheatmasstransfer.2020.104685

8. Zhao J., Lio Q., Huang H., Yang R., Zhang H. Experiments investigating fuel spread behaviours for continuous spill fires on fireproof glass // Journal of Fire Sciences. 2017. V. 35(1). P. 80-95. doi: 10.1177/0734904116683716

9. Seo J., Lee J. S., Kim H. Y., Yoon S. S. Empirical model for the maximum spreading diameter of low-viscosity droplets on a dry wall // Experimental Thermal and Fluid Science. 2015. V. 61. P. 121-129. doi: 10.1016/j.expthermflusci.2014.10.019

10. Abramov Yu., Basmanov O., Krivtsova V., Salamov J. Modeling of spilling and extinguishing of burning fuel on horizontal surface // Naukovyi Visnyk NHU. 2019. V. 4. P. 86-90. doi: 10.29202/nvngu/2019-4/16

11. Raja S., Abbasi T., Tausef S. M., Abbasi S. A. Equilibrium models for predicting areas covered by accidentally spilled liquid fuels and an assessment of their efficacy // Process Safety and Environmental Protection. 2019. V. 130. P. 153-162. doi: 10.1016/j.psep.2019.08.009 
12. Meel A., Khajehnajafi S. A comparative analysis of two approaches for pool evaporation modeling: Shrinking versus nonshrinking pool area // Process Safety Progress. 2012. V. 34. P. 304-314. doi: 10.1002/prs.11502

13. Tokunaga T. K. Simplified Green-Ampt Model, Imbibition-Based Estimates of Permeability, and Implications for Leak-off in Hydraulic Fracturing // Water Resources Research. 2020. doi: 10.1029/2019WR026919

14. Ramli H., Zabidi H. A. Effect of oil spill on hydraulic properties of soil // Malaysian construction research journal. 2015. V. 49. URL: https://www.academia.edu/download/62252229/MCRJ_V19N2_520200302-87581109jtez.pdf

15. Abramov Y. A., Basmanov O. E., Mikhayluk A. A., Salamov J. Model of thermal effect of fire within a dike on the oil tank // Naukovyi Visnyk NHU. 2018. V. 2. P. 95-100. doi: 10.29202/nvngu/2018-2/12

\author{
Y. Abramov, DSc, Professor, Chief Researcher \\ O. Basmanov, DSc, Professor, Chief Researcher \\ V. Oliinik, PhD, Associate Professor, Deputy Head of Department \\ National University of Civil Defence of Ukraine, Kharkiv, Ukraine

\section{MODELING THE SPILLING OF FLAMMABLE LIQUID IN A CASE OF RAILWAY ACCIDENT}

\begin{abstract}
The paper considers the forecasting of the consequences of emergencies caused by the spillage of combustible liquids in railway transport by building mathematical models of the dynamics of spreading the combustible liquid and its infiltrating into the soil. A mathematical model contains a system of two differential equation. The first of them is an equation of parabolic type and describes the dynamics of changing the height of the liquid layer. The second describes the depth of liquid infiltrated into the soil. It is shown that infiltrating into the soil significantly affects to the dynamics of liquid spreading. So it should be taken into account for a correct assessment of the consequences of an emergency caused by damage to the tank with combustible liquid. For the case of instantaneous destruction of a tank with liquid, the system of equations is supplemented by initial conditions that contain a singularity. It is the function at the point of accident. It is shown that a mathematical model of the gradual outflow of liquid from a damaged tank can be obtained by introducing into the differential equation a term describing the source of outflow of liquid. A method for estimating the parameters of the model of liquid infiltration into the soil is proposed. It is based on measuring the impregnation depth at certain points in time and finding such values of suction head, hydraulic conductivity and soil porosity that provide minimal deviation between the calculated depth and experimentally determined depth. The analytical solution of the equation of liquid infiltration is used for calculating the depth. The method of least squares is used as a criterion. The proposed models can be used for forecasting the consequences of the thermal impact of the fire of fuel spill on the rolling stock and technological structures of the railway.
\end{abstract}

Keywords: emergency, spill, combustible liquid, forecasting, spreading and infiltration

\title{
References
}

1. Raja, S., Tauseef, S. M., Abbasi, T. (2018). Risk of Fuel Spills and the Transient Models of Spill Area Forecasting. Journal of Failure Analysis and Prevention, 18, 445-455. doi: 10.1007/s11668-018-0429-1

2. Chernetskiy, V. V., Fedunkiv, V. S., Kochkodan, T. I. (2015). Organization of management of forces and means of operative-rescue service of civil protection at liquidation of fires of oil products on the railway transport. Problems of civil protection: controlling, warnings, rescue and special works, 131-137. Retrieved from http://edumns.org.ua/img/news/6041/fedunkiv.doc 
3. Huang, W., Shuai, B., Zuo, B., Xu, Y., Antwi, E. (2019). A systematic railway dangerous goods transportation system risk analysis approach: The 24 model. Journal of Loss Prevention in the Process Industries, 61, 94-103. doi: 10.1016/j.jlp.2019.05.021.

4. Dindar, S., Kaewunruen, S., An, M., Osman, M. H. (2016). Natural Hazard Risks on Railway Turnout Systems. Natural Hazard Risks on Railway Turnout Systems, 161, 1254-1259. doi: 10.1016/j.proeng.2016.08.561

5. Etkin, D., Horn, M., Wolford, A. (2017). CBR-Spill RISK: Model to Calculate Crude-by-Rail Probabilities and Spill Volumes. International Oil Spill Conference Proceedings, 3189-3210. doi: 10.7901/2169-3358-2017.1.3189

6. Zhao, X., Chen, C., Shi, C., Zhao, D. (2019). An extended model for predicting the temperature distribution of large area fire ascribed to multiple fuel source in tunnel. Tunnelling and Underground Space Technology, 85, 252-258. doi: 10.1016/j.tust.2018.12.013

7. Pan, Y., Li, M., Luo, X., Wang, C., Luo, Q., Li, J. (2020). Analysis of heat transfer of spilling fire spread over steady flow of n-butanol fuel. International Communications in Heat and Mass Transfer, 116. doi: 10.1016/j.icheatmasstransfer.2020.104685

8. Zhao, J., Liu, Q., Huang, H., Yang, R., Zhang, H. (2017). Experiments investigating fuel spread behaviors for continuous spill fires on fireproof glass. Journal of Fire Sciences, 35(1), 80-95. doi: 10.1177/0734904116683716

9. Seo, J., Lee, J. S., Kim, H. Y., Yoon, S. S. (2015). Empirical model for the maximum spreading diameter of low-viscosity droplets on a dry wal. Experimental Thermal and Fluid Science, 61, 121-129. doi: 10.1016/j.expthermflusci.2014.10.019

10. Abramov, Yu., Basmanov, O., Krivtsova, V., Salamov, J. (2019). Modeling of spilling and extinguishing of burning fuel on horizontal surface. Naukovyi Visnyk NHU, 4, 86-90. doi: 10.29202/nvngu/2019-4/16

11. Raja, S., Abbasi, T., Tauseef, S. M., Abbasi, S. A. (2019). Equilibrium models for predicting areas covered by accidentally spilled liquid fuels and an assessment of their efficacy. Process Safety and Environmental Protection, 130, 153-162. doi: 10.1016/j.psep.2019.08.009

12. Meel, A., Khajehnajafi, S. (2012). A comparative analysis of two approaches for pool evaporation modeling: Shrinking versus nonshrinking pool area Process Safety Progress, 34, 304-314. doi: 10.1002/prs.11502

13. Tokunaga, T. K. (2020). Simplified Green-Ampt Model, Imbibition-Based Estimates of Permeability, and Implications for Leak-off in Hydraulic Fracturing. Water Resources Research. doi: 10.1029/2019WR026919

14. Ramli, H., Zabidi, H. A. (2015). Effect of oil spill on hydraulic properties of soil. Malaysian construction research journal, 49. Available online: https://www.academia.edu/download/62252229/MCRJ_V19N2_520200302-87581109jtez.pdf

15. Abramov, Y. A., Basmanov, O. E., Mikhayluk, A. A., Salamov, J. (2018). Model of thermal effect of fire within a dike on the oil tank. Naukovyi Visnyk NHU, 2, 95-100. doi: 10.29202/nvngu/2018-2/12 